Arab World English Journal (AWEJ) Volume 12. Number2 June 2021

DOI: https://dx.doi.org/10.24093/awej/vol12no2.22

Pp. 318-329

\title{
Functional Aspects of Interlingual Borrowings: Current Challenges
}

\author{
Oksana Slaba \\ Department of Foreign Languages, Faculty of Economics and Law \\ Kyiv National Linguistic University, Kyiv, Ukraine \\ Yaroslava Padalko \\ Department of Foreign Languages, Faculty of Economics and Law \\ Kyiv National Linguistic University, Kyiv, Ukraine \\ Olena Vasylenko \\ Department of Foreign Languages, Faculty of Economics and Law \\ Kyiv National Linguistic University, Kyiv, Ukraine \\ Larysa Parfenova \\ Department of Foreign Languages, Faculty of Economics and Law \\ Kyiv National Linguistic University, Kyiv, Ukraine
}

Received: 3/30/2021 Accepted: 6/10/2021 Published: 6/24/2021

\begin{abstract}
A particular status of the English language as the language of international communication and connections between the nearly related English and German languages resulted in the emergence of many interlingual borrowings in the Modern English and German language vocabularies. The paper aims to consider the functioning of borrowings (loanwords) in the English and German languages. To reach the aim of the research and to carry out the tasks assigned, the following methods were used: a descriptive method, the method of correlation, componential analysis and, comparative semantic analysis. The paper focuses on linguistic and extralinguistic factors of the German and English interaction. Special attention is paid to clarifying the notion of borrowing in modern linguistic science. The word-formative calques and half-calques (hybrids), which differ from ordinary lexical borrowings by using partially borrowed lexical material, are identified in addition to direct lexical borrowings in the language subsystem under study. The paper demonstrates the significant influence of English borrowings on the structural-semantic qualities of German words, on various semantic changes, as well as on the participation of loanwords in the lexico-semantic variation: synonymy, polysemy, homonymy, and antonymy. The results of the research can also be used in the teaching and learning of both languages, in the course of lexicology or linguistics.

Keywords: English and German languages, external and internal factors, functional aspects, interlingual borrowing, loanwords

Cite as: Slaba, O., Padalko, Y., Vasylenko, O., \& Parfenova, L. (2021). Functional Aspects of Interlingual Borrowings: Current Challenges. Arab World English Journal, 12 (2) 318-329.

DOI: https://dx.doi.org/10.24093/awej/vol12no2.22
\end{abstract}




\section{Introduction}

Modern linguistic science recognizes that one of the most important external factors of language changes and development is contacting of languages, which is one of the most powerful stimuli of language changes (Carstensen, 1992; Rozen, 2000; Siemund, 2008; Vennemann, 2011; Weinreich, 1979). Today, language contacts are regarded as one of the aspects of creative activities in a language.

The researches done over the last years testify to the fact (Dyakov, Kyyak, \& Kudelko, 2000; Kapush, 2016) that the language system is complicated in its elementary, structural, functional, and other qualities due to the evolutionary processes, which certify one of the postulates of the modern linguistics on the development of any language. This development takes place as a struggle of the two differently directed tendencies - to preservation and stabilization of the existing language system, on the one hand, and to its adaptation, reconstruction, improvement, on the other hand.

At the beginning of the $21^{\text {st }}$ century, the expansion and emergence of new fields of nomination caused by the rapid development of science, technology, mass media were observed. In different epochs of language development, certain types of nominative processes are in effect. At present, borrowing is an especially active type of creating nominations of any language that is of interest of many linguists of the current time (Dyakov, et al., 2000; Kapush, 2016; Winford, 2010). However, borrowings in the German and the English languages, considering functional aspects, were not the research object.

The paper aims to analyze the specific features of the functioning of borrowings in the German and English languages. To reach this aim, it is required to fulfill the following tasks: to specify the notion of borrowing in the modern linguistic science, to qualify the linguistic and extralinguistic factors that stimulate an entry of borrowings into the lexical-semantic system of English and German; to single out and characterize the types of borrowing that function in the vocabularies of both languages; to identify the influence of borrowings on the semantic (synonymic, polysemic, homonymous and antonymic) processes in the sphere of the vocabulary under study.

The scientific novelty of the paper is in systematic research of interlingual borrowings taking into account the semantics and lexical levels. The significance of the study consists in revealing the interaction of the English borrowed vocabulary with the German one, as well as identifying the main features of their functioning.

\section{Literature Review}

The linguists like Haugen (1950), Weinreich (1979), and Winford (2010) have recognized that a study of lexical systems is associated with some systemic characteristics, not only solely linguistic but also socio-linguistic, psycholinguistic, etc., which closely intercommunicate. A prominent place among the characteristics indicated is held by a sociallanguage situation of a "lexical gap" (Karpenko, 1995; Marouane, 2014), which is a motivating factor of unceasing development of the language vocabulary determined by a socially induced need for nominating new denotations which should be satisfied by the language in the process of its evolution. As a rule, this need is satisfied by each language along with the following principal 
directions: 1) creating lexical units and their equivalents owing to derivational possibilities and semantic derivation; 2) borrowing ready-to-use lexical units from other languages.

Borrowing is a natural process of language development, and no language in the world, except in very rare exceptions, can avoid contacting other languages. The term "borrowing" is used in modern linguistics in two meanings. In the broad sense, "borrowing" is regarded in connection with the theory of language contact, with the interaction of language systems as one of the ways for an enrichment of the language vocabulary (Haspelmath, 2009; Hock \& Brian, 2009).

The term "borrowing" is used in the narrow sense for indicating the process of an entry and adaptation of the vocabulary borrowed which is transferred from one language to another one as a result of language contacts but not as a result of historical (genetic) development for an improvement of the language as a means of communication and perception (Carstensen, 1992; Haugen, 1950).

Direct borrowings are one of the most productive methods of replenishing a language vocabulary. In this case, a direct transfer of phonetic and morphological variants of lexical units occurs from the producer language to the receptor language (Kudelko, 2017). There are two types of direct borrowings: complete and partial ones. The linguists have referred to the first type the lexical units, which emerged in the vocabulary of the language as a result of the process of borrowing both an internal and external form. The second type of direct borrowings is presented by the lexical units that are borrowed if the language contains the notions whose formal and external expression they are. Modern researchers (Dyakov, et al., 2000) have qualified this type of direct borrowings as a partial one. The primary method of their creation is modeling words and constructions after foreign patterns (calque or loan translation) that is a literal translation of word elements from the producer language into the receptor language, for example, in German Mittelalter, in English - the Middle ages.

The lexical-word-formative calques (loan-translation) include the borrowings, which have a consequent and literal translation of all elements in the receptor language from the producer language. The researchers identify as half-calques the words or the word combinations created at the moment of translation of a word or word combination by eliminating or adding a certain element. Weinreich (1979) has classified them as loan renditions.

Permanent changes in the vocabulary of any language are testified by its reconstruction, reorganization of multiple interconnections between the vocabulary components, which are conditioned by both linguistic and extralinguistic factors. Rozen (2000) has emphasized that the linguistic factors include, first of all, empowerment for a more accurate representation of the objective reality, its verbalization, an aspiration for overcoming a nominative deficiency and for the unification of the language means, an ambition of native speakers to fill up, intensify and widen the concept of subject or phenomenon, to work out in detail the notions and features by delimitating their semantic and functional connotations, etc.

In recent decades, quantitative and qualitative changes have been taking place as a result of the influence of extralinguistic factors in the processes of borrowing and adoption of the 
vocabulary borrowed. Social and economic development, an introduction of new information technologies, general computerization cause penetration of anglicisms into all languages of the world, step up their adaptation, thus calling for a need for their comprehensive study (Kudelko, 2017).

In addition to the linguistic factors indicated, the extralinguistic factors are also active here, in particular: the penetration of anglicisms into the German language vocabulary is indebted to the fact of recognizing the English language (its American English) as an international language (Carstensen, 1992). Anglicisms serve as a means of filling those holes that arise in connection with a conceptual space extension of the world model, which, in its turn, is the result of the scientific and technical progress of modern civilization.

Mozhova and Sheverun (2018) have held that the process of borrowing a significant number of lexical elements by the English language is an essential driving force in the development of the English language vocabulary.

A relatively progressive tendency of developing many languages of the world towards internalization of scientific and technical terms is an important extralinguistic factor, that is a peculiar projection of the state of existence of a respective field of science, technology, and culture of modern society. Among the extralinguistic factors, it is also worth mentioning various relations of the German people with the English people and with other peoples of the world. Here, one cannot but consider the intercommunal development of the societies, the progress of science and technology, etc. Borrowing a word together with the borrowed subject, phenomenon, quality, action, etc., is a form of implementing such connections. These processes are especially characteristic of the initial stages of developing any language (Kapush, 2016).

At present, the English language is widespread in many countries. English is one of the working languages of the United Nations. A significant amount of fiction and scientific and technical literature is published in it. At the beginning of colonial seizures, when the English language was barely entering new lands, England was a center of the language norm, and it continued to be such a center for quite some time (Rozen, 2000).

At the end of the $19^{\text {th }}$ century, Northern American English began to play an ever-greater role. A particular norm of the English language was formed not only in North America but also in Australia. In addition to the USA, Canada, Australia, and New Zeeland, the English language is used in more than 50 developing countries in Asia, Africa, and America (Durkin, 2014).

\section{Methods}

To reach the aim of the research and carry out the tasks assigned, the following methods were used: a descriptive method for systematization, classification, interpretation of the structural, semantic, and functional qualities of borrowings at present of the language development; the method of correlation of the linguistic and extralinguistic phenomena for determining interconnection of historical changes in the life of English and German native speakers and the penetration of borrowings into the vocabularies of the English and German languages; a componential analysis of the lexical meanings for determining and describing the semantic structure of the borrowings under study; a comparative semantic analysis for 
identifying the categories which reflect the semantic relations of the borrowings - synonymy, antonymy, polysemy, homonymy, etc.

\section{Procedures}

The first stage of the study provides for forming a theoretical basis of the scientific research and singling out borrowings in English and German. The theoretical principles of the study are based on using the general scientific methods, namely: a descriptive method, a generalization method that provided an identification of the essential theoretical data on the problems chosen with the purpose of their detailed analysis and description.

The second stage of the research focused attention on a complex analysis of the structural characteristics of borrowings in English and German. A componential analysis of lexical meanings is applied for specifying and describing the semantic structure of the borrowings under study.

At the third stage, a comparative semantic analysis made it possible to reveal the categories, which reflect the semantic relations of the borrowings - synonymy, antonymy, polysemy, homonymy, etc.

\section{Results}

The researchers have also identified direct borrowings in the analyzed materials. These borrowings carry new knowledge, thus extending the conceptual world model. Complete borrowing provides for adapting a lexical unit to phonetic (sound changes, syllable restructuring) and morphological characteristics (subordination to the system of gender, conjugation) of the language.

The researchers have also identified lexical-word-formative calques and half-calques (hybrids) among the borrowings under study. Table 1 demonstrates some examples of borrowings from English into German.

Table 1. Examples of borrowings from English into German

\begin{tabular}{|c|c|c|}
\hline Type of borrowings & English & German \\
\hline direct borrowings & computer, fan, team, to manage & $\begin{array}{c}\text { der Computer, der Fan, } \\
\text { das Team, managen }\end{array}$ \\
\hline $\begin{array}{c}\text { lexical-word-formative } \\
\text { calques }\end{array}$ & $\begin{array}{c}\text { detter Kreditbrief, } \\
\text { Buyback, cash before delivery }\end{array}$ & $\begin{array}{c}\text { die Finanzpolitik, der Rückkauf, } \\
\text { Zahlung vor Lieferung }\end{array}$ \\
\hline half-calques (hybrids) & $\begin{array}{c}\text { traveler's cheque, time charter, Full- } \\
\text { time-Job, shopping-center }\end{array}$ & $\begin{array}{c}\text { der Reisescheck, der Zeitcharter, } \\
\text { die Ganztagsarbeit, } \\
\text { das Einkaufszentrum }\end{array}$ \\
\hline
\end{tabular}

The first German borrowings in the English language vocabulary belong to the $16^{\text {th }}$ century. During this period, the words connected with trade, the art of war, the names of some plants, terms certain professions, social statuses, etc., were borrowed, for example, halt "stop," lance-knight "Landsknecht," kreuzer "kreutzer - the name of a coin," junker "cadet." 
As long ago as the $16^{\text {th }}$ century England began active mining of ore deposits, developed its metallurgy. At that time, Germany was an advanced country in mining and metallurgy industry, and that is why many specialists were arriving in England from Germany. In consequence of direct communication with German-speaking people, oral borrowing of German words took place first. In written documents, these words emerged not earlier than in the $17^{\text {th }}$ century. Such terms of the mining industry as zinc, bismuth, cobalt and others made their way into the English language from German.

In the $17^{\text {th }}$ century, new borrowings in the spheres of trade and art of war emerged in the English language, for example, groschen "farthing, old German silver coin," drilling "geology triplet, a growth of three crystals," field marshal "field marshal" and others.

In the $18^{\text {th }}$ century, the influence of the German language on the English language happened to be weaker than that in the previous century. This phenomenon can be explained apparently by Germany's general economic and political decline after the prolonged war. In the second half of the $18^{\text {th }}$ century, some words from geology, mineralogy, and mining were borrowed: iceberg, wolfram, nickel, glitchier.

From the end of the $18^{\text {th }}$ century, the language influence of England, as a leading country with advanced technology, was making itself felt increasing. The English lexical units associated with social and political life, trade, industry and finance, railways, and navigation were borrowed into the German language, for example, in public and political life: das Parliament, das Bill, das Interview; economic life: der Export, die Obligation, die Banknote, der Trust. Many of these English words that became international are derived from French and Latin and a considerable part of English vocabulary, in general. Still, it was the English language wherein some of them acquired that special meaning to enter the international vocabulary.

In the $19^{\text {th }}$ century, the sphere of borrowings from German into English expanded significantly. Some borrowings from the field of Human Sciences, public life, and politics came into existence. A lot of terms were borrowed in the areas of chemistry, physics, linguistics, art. Many of these borrowings are calques or international words. Thus, some terms which also are present in the field of linguistics until now were borrowed, for example, Indo-Germanic (Indogermanisch), Middle English (Mittelenglisch), umlaut, ablaut, folk etymology (Folksetymologie), Loanword (Lehnwort). During this period, the English language was penetrated by mean foodstuffs and household items: marzipan, kohl-rabi, schnapps, kummel, kirsch, vermuth; the terms from the area of music: leitmotiv, kapellmeister, humoresque; names of animals: spitz, poodle.

Borrowings of the $20^{\text {th }}$ century are characterized by the noticeable dominance of the words associated with war. The most well-known of them are: black shirt (Schwarzhemd), brown shirt (Braunhemd), Gestapo, Hitlerism, Nazi, storm-trooper (Sturmabteilungsman), the Third Reich (das Dritte Reich), blitzkrieg, bunker, Luftvaffe, Wermacht.

After the First World War, the influence of English on German strengthened, and after the Second World War, it reached an unprecedented scale. As a result of the partition of Germany and the creation of two separate countries with two different social and political 
systems, the language development showed a tendency for divergence and formation of stable differential markers that became the object of special attention of the researchers of both German states. The results of language contacts, which were directly dependent on the ruling ideologies in these countries, were also distinctive for the German language in East Germany and West Germany.

The reunification of Germany, a new event in the life of the German nation, gave a new impetus for an anglicism penetration into the German language. The changes in social and political life were closely linked with the language changes. This extralinguistic factor contributed to increasing the number of neologisms to identify the historical events of the transitional period and new social realities: die Maueröffnung, der Mauerspecht, die Umweltunion, die DM-Einfürung, die Kontoumstellung, etc.

Analyzing the linguistic material (loanwords) enables us to state that the influence of borrowings in the English and German vocabularies takes place in different ways. Borrowings in the German language have a significant impact on the structural and semantic features of the German words, change their internal structure and stylistic coloring, and contribute to establishing homonymic, synonymous, and semantic relations.

Taking into account the diversity of the borrowing process results, we'll consider in this work the basic semantic relations in the field of the vocabulary being examined and the specificity of its formation, which are facilitated by English borrowings. Thus, anglicisms facilitate establishing synonymous relations.

Synonyms occupy a central place in semantic relations of any language since they contribute to the differentiation of homonyms and polysemous words. We adhere to the opinion that synonyms emerge readily as factors of more rational denotation, as a result of a new denomination, as a manifestation of consistency, and as a result of borrowing.

The English borrowing Cash came into the German language with the meaning "cash; cash from the till; coins and paper money (checks and promissory notes, which are due to payment)." In German, it is in a synonymous relationship with the terms das Bargeld - die Barzahlung. In this case, the German words specify various undertones of the English borrowing's meaning.

The historical tradition in the German language is to resist loanwords, to use the wordforming means of the German language to create lexical equivalents to the lexical units borrowed. This tradition led to the emergence of a considerable number of synonymous words of such a type.

An analysis of the language material also shows the presence of various distinctive features, namely: 1) the existence of complete (absolute) synonyms that coincide in all aspects and can be replaced: die Verrechnung - das Clearing "mutual settlement, clearing," die Ausfuhr - der Export "taking out, export (goods)," die Einfuhr - der Import "importation, import of (goods)." 
2) Partial synonyms, which partially coincide in their meanings. They differ in the ratio of part and whole, abstract and concrete, etc., but they all serve to express the same notion.

The German word der Geschäftsführer has several meanings, namely: 1) administrator, managing director; manager, 2) commercial director. The following synonyms can be selected for the first connotation: der Leiter, der Verwalter, der Administrator, der Direktor. And the last two words are borrowed from Latin in their first meaning. The second meaning of the word der Geschäftsführer corresponds to the phrase kaufmännischer Leiter or the English borrowing der Manager. Thus, the following synonymous series are formed: der Geschäftsführer - der Verwalter - der Administrator - "administrator, manager" and der Geschäftsführer - der Leiter der Manager - "manager, commercial director".

3) Relative synonyms, which are such only in the context. The facts of language, which the researchers examine based on semantic oppositions, allow us to consider the analyzed borrowings in close connection with each other. They are interconnected by the relations of oppositions. Thus, borrowings also contribute to the formation of antonymous relations. A qualitative feature in the meaning of a word is required for the emergence of antonymy. Therefore, this semantic category characterizes, as a rule, adjectives and corresponding adverbs and nouns. As a purely conceptual phenomenon, antonymy refers to general vocabulary and terminology. It helps to mark the extreme edges of the terminological field and the logical possibilities of the terminological system: der Export-der Import; bargeldlos - bar, cash; fester Kurs - frei schwankender Kurs (das Floaten).

The development of polysemy is conditioned by the law of asymmetry of the sign and meaning. Thanks to this, the original Lexical-Semantic Variant (LSV), adapting to the specific conditions of different spheres of functioning (different types of text), gives an impetus to the emergence of a new LSV. Semantic variation of lexical units takes place as long as similarity outweighs difference. If the difference starts to prevail, then it is homonymy.

Polysemy, as a semantic phenomenon, is profoundly conceptual and is related only to those words that have clear connections with concepts. A polysemous word is correlated with several concepts (according to the number of LSV), which indicates the absence of direct coincidence of a word and a concept: the word is one, but the concepts are two or several.

An analysis of the factual material under study shows that monosemy and polysemy equally occur in the special and common vocabulary. German term der Bonus, originated from English bonus, has several meanings, namely: 1) stock exchange premium, premium in exchange transactions; 2) profit, profit share; 3) bonus, discount; free surcharge for a large purchase; 4) export premium. In sports, this word is also used in the sense of "handicap or odds."

Also, the noun der Change was borrowed from English into German with several meanings, namely: 1) (bargain) exchange; 2) exchange office; 3) exchange rate.

Homonyms are words that sound the same but have different meanings. This phenomenon is not purely conceptual as synonymy or polysemy is. The primary sources of homonymy are 1) convergence of words; 2) delimitation of two or more meanings of a 
polysemous word, divergence; 3) metaphor and metonymy; 4) borrowing from different languages.

The corpus of anglicisms the researchers have studied testifies to one of the presented sources of homonymy. The verb schiften in construction means 1) to measure the angles and dimensions of the beams, which are obliquely adjacent to each other; 2) cut surface (beams); 3 ) to join with nails (beams). The same verb has acquired the meaning "to be replaced (referring to cargo)" under the influence of English to shift - "move, shift" and is used in maritime affairs. Abbreviation names can also be homonymous: Co. - "cobalt (chemical symbol)" and Co. abbreviation from Compagnie, Kompanie.

Language as the primary tool of communication, thinking, and knowledge transfer is constantly evolving. Everything new that appears in our world needs its expression, description, and denotation. The lexical-semantic system of the language reacts as quickly as possible to changes in society and the worldview of a person. Searching for new lexical means for transferring new knowledge activates word-forming processes, changes in the semantics of specific lexical units, and borrowing processes, which are the primary forms of neologisms creation and replenishment of the language word-stock.

In the pandemic of coronavirus infection, significant changes in society and worldview can be observed, as evidenced by the considerable activation of neologism formation and borrowing of new words, which have been occurring in 2020-2021. The word corona from the phrase coronavirus and the abbreviation covid (written in both uppercase and lowercase letters) were borrowed from English, not only by German but also by many other languages. Covid was borrowed as anglicism, and users of the languages such as French, Catalan, Spanish, and Italian, as a rule, tend to prefer the masculine gender because of its associations with the (corona) virus (Roig-Marin, 2020).

A common way to denote new realities is to use borrowings. As the fight against coronavirus is a global problem for the whole world, new borrowings from English, as a language of international communication, have emerged. The major part of borrowed lexemes are nouns (see Table 2):

Table 2. New borrowings from English into German

\begin{tabular}{|c|c|c|}
\hline & borrowings & meaning \\
\hline 1. & Spreading & rapid dissemination of the infection \\
\hline 2. & Weaning & slow separation of an intensive care patient from artificial ventilation \\
\hline 3. & Lockdown or Shutdown & $\begin{array}{l}\text { a period of cessation of economic and social activities at the state level } \\
\text { for security reasons }\end{array}$ \\
\hline 4. & Containment & $\begin{array}{l}\text { suppression of the epidemic by tracking infectious chains, and } \\
\text { quarantine of infected people }\end{array}$ \\
\hline 5. & Contact tracking & identifying contacts of infected persons \\
\hline 6. & Hotspot & coronavirus outbreak \\
\hline 7. & Homeworking & work at home \\
\hline 8. & Home Work-out & fitness training at home \\
\hline
\end{tabular}


However, the researchers have also observed the borrowing of individual verbs: tracen to track the contacts of digital devices of people (without location data); tracken - to track the location of people; videochatten - to communicate in video chat.

\section{Discussion}

Lexical borrowings in the English and German vocabularies hold a significant place. It is explained by the fact that over a long period, England and Germany, in different epochs, fell under the economic, political, and cultural influence of other countries (Vennemann, 2011; Weinreich, 1979).

The analysis of the research results of the linguists (Carstensen1992; Kapush, 2016) and the conducted research have shown that nowadays, language contacts are especially intense due not only to linguistic but also extralinguistic factors. The scientific and technological progress, the emergence of new scientific directions, and the revision of the traditional scientific knowledge systems require forming new words to denote new concepts, processes, etc. Based on the material analysis and the research results of the linguists, it is possible to make a conclusion (Carstensen, 1992; Haspelmath, 2009; Rozen, 2000; Winford, 2010) that at the end of the $20^{\text {th }}$ century - at the beginning of the $21^{\text {st }}$ century, borrowings become the primary source of replenishment and updating of the vocabulary of any language.

\section{Conclusion}

The research aimed to consider the peculiarities of the functioning of borrowings in the English and the German languages made it possible to identify two types of direct borrowings: complete and partial. The researchers singled out the lexical-word-forming calques and halfcalques among them. It is established that the process of borrowing is multifaceted, and its result is not only the replenishment of the lexicon but also certain changes in the word-stock structure: in the number and composition of different groupings of words, their linguistic relationships, etc. It also contributes to the variability of lexical units. It largely determines this variability, which leads to the formation of polysemy, homonymous, synonymous and antonymous relations in the vocabulary of the English and the German languages.

The results have made it possible to understand the interaction mechanism of the English and German languages in the context of interlingual contacts. The research results can also be used in the teaching and learning of both languages, in the course of lexicology or linguistics.

\section{About the Authors}

Oksana Slaba, Ph.D. in Philology, Associate Professor at the Department of Foreign Languages, Faculty of Economics and Law, Kyiv National Linguistic University, Ukraine. Her research interests include linguistics, cross-cultural studies, teaching foreign languages.

ORCID ID: https://orcid.org/0000-0001-5155-4554

Yaroslava Padalko, Senior teacher at the Department of Foreign Languages, Faculty of Economics and Law, Kyiv National Linguistic University, Ukraine. Her research interests include linguistics, cross-cultural studies, teaching English in multicultural class.

ORCID ID: https://orcid.org/0000-0003-0016-4737 
Olena Vasylenko, Senior teacher of the Department of Foreign Languages, Faculty of Economics and Law, Kyiv National Linguistic University, Ukraine. Her research interests include English for specific purposes (for lawyers, managers), teaching in multicultural groups. ORCID ID: https://orcid.org/0000-0001-9542-2094

Larysa Parfenova, Ph.D. in Pedagogy, Associate Professor at the Department of Foreign Languages, Faculty of Economics and Law, Kyiv National Linguistic University, Ukraine. Her research interests include linguistics, cross-cultural studies, teaching English for specific purposes. ORCID ID: https://orcid.org/0000-0001-5659-2699

\section{References}

Carstensen, B. (1992). Anglicisms in German: the description of the loan-process. In $\mathrm{Hg}, \mathrm{G}$. Meder \& A. Dorner, (eds.), Lexikographische Beiträge zum Essener Linguistischen Kolloquium. [Lexicographical reports ap the Essen Linguistics Colloquium] (pp. 87103). Tubingen: Niemeyer.

Durkin, Ph. (2014). Borrowed Words: A History of Loanwords in English. DOI:10.1093/acprof:oso/9780199574995.001.0001

Dyakov, A. S., Kyyak, T. R., \& Kudelko, Z. B. (2000). Fundamentals of Terminology: Semantic and Socio-linguistic Aspects. Kyiv: Academia.

Haspelmath, M. (2009). Lexical borrowing: Concepts and issues. In M. Haspelmath \& U.Tadmor (eds). Loanwords in the World's Languages: A Comparative Handbook. (pp. 35-54). Berlin: De Gruyter Mouton.

Haugen, E. (1950). The analysis of linguistic borrowing. Language. 26, 210-231 http://dx.doi.org/10.2307/410058

Hock, H., \& Brian, D. (2009). Language History, Language Change, and Language Relationship: An Introduction to Historical and Comparative Linguistics (2nd ed.). Berlin: Mouton de Gruyter.

Kapush, A. V. (2016). Language Situation in Europe under the Dominant Influence of the English Language (by the Example of German). Scientific Notes of Nizhyn Mykola Gogol State University. Series: Philological sciences. 1, 8-12. Available at http://nbuv.gov.ua/UJRN/Nzfn_2016_1_3

Karpenko, M. O. (1995). The Socio-linguistic situation of "lexical gap" and the process of neologization in East Slavic languages. Languages of the European cultural area: problems of development and interaction: Proceedings of the 1-st International Scientific Conference in memory of Yu.O. Zhluktenko (pp. 48-49). Kyiv.

Kudelko, Z. B. (2017). The Influence of Borrowings and Internationalism on the Development of Diplomatic Terminology. Current issues of Social Studies and History of Medicine. Joint Ukrainian-Romanian scientific journal, 4, 126-129. Available at https://docs.google.com/viewer?a=v\&pid=sites\&srcid=YnNtdS51ZHUudWF8YXBzbmltf Gd4OjIxNGFiZTE2YzRmMDc0NTA

Marouane, M. (2014). The Impact of Translation on the Moroccan Political Discourse. Arab World English Journal, 5 (2), 142-152. Available at https://awej.org/images/AllIssues/Volume5/Volume5Number2June2014/12.pdf

Mozhova, Y., \& Sheverun, N. (2018). Functions of German Words in English Political and Economic Text. Scientific Notes of Ostroh Academy National University. Serie: Philology, 4 (72), 3-5. Available at https://journals.oa.edu.ua/Philology/article/view/2103 
Roig-Marín, A. (2020). English-based coroneologisms: A short survey of our Covid-19-related vocabulary. English Today, 1-3. https://doi.org/10.1017/S0266078420000255

Rozen, Ye. V. (2000). On the Threshold of the 21st Century. New German Words and WordCombinations. Moskwa: Menedzher.

Siemund, P., \& Kintana, N. (Eds.). (2008). Language contact and contact languages, 7. John Benjamins Publishing. https://doi.org/10.1075/hsm.7

Vennemann, T. (2011). English as a Contact Language: Typology and Comparison. Anglia, 129 (3-4), 217-257. https://doi.org/10.1515/angl.2011.084

Weinreich, U. (1979). Languages in Contact: Findings and Problems. New York: Mouton.

Winford, D. (2010). Contact and Borrowing. In Hickey R. (eds). The Handbook of Language Contact (pp. 170-187). Blackwell Publishing Ltd https://doi.org/10.1002/9781444318159.ch8 